Universidade de Brasília

FACULDADE DE ECONOMIA, ADMINISTRAÇÃO. CONTABILIDADE E CIÊNCIA DA INFORMAÇÃO E DOCUMENTAÇÃ̃O - FACE

LILIANE MARIA BELO DO AMARAL

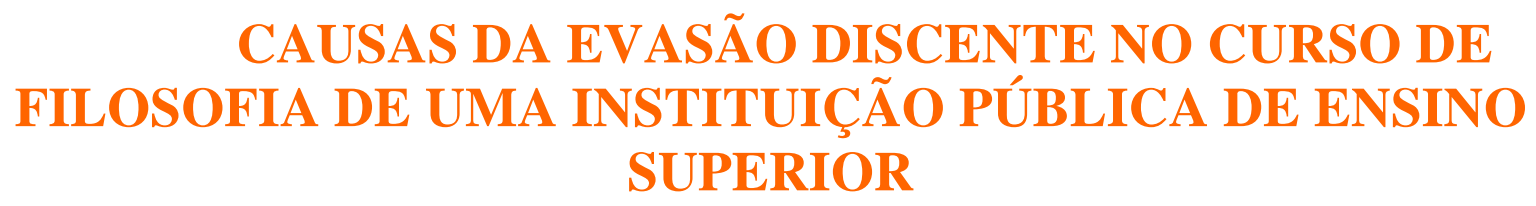

Brasília - DF 
LILIANE MARIA BELO DO AMARAL

\section{CAUSAS DA EVASÃO DISCENTE NO CURSO DE FILOSOFIA DE UMA INSTITUIÇÃO PÚBLICA DE ENSINO SUPERIOR}

Monografia apresentada ao Programa de PósGraduação em Administração da Faculdade de Economia, Administração, Contabilidade e Ciência da Informação e Documentação (FACE), da Universidade de Brasília, como requisito parcial à obtenção do grau de Especialista em Gestão Universitária.

Orientadora: Profa Dra. Maria de Fátima Bruno de Faria 
LILIANE MARIA BELO DO AMARAL

\section{CAUSAS DA EVASÃO DISCENTE NO CURSO DE FILOSOFIA DE UMA INSTITUIÇÃO PÚBLICA DE ENSINO SUPERIOR}

Monografia foi julgada pelo Programa de Pós-Graduação em Administração da Faculdade de Economia, Administração, Contabilidade e Ciência da Informação e Documentação (FACE), da Universidade de Brasília, como requisito parcial à obtenção do grau de Especialista em Gestão Universitária.

Professora Dra. Maria De Fátima Bruno De Faria

Orientadora

Professora Dra. Catarina Cecília Odelius

Membro interno 
À minha familinha,

Rodrigo e Vitória pelo incentivo e companheirismo. 


\section{AGRADECIMENTOS}

Quando iniciei o curso havia apenas uma semana do falecimento da minha mãe, a qual chamávamos (eu e meus irmãos) de nosso bebê. E então quero agradecer a Deus pela experiência que ele nos permitiu de conhecê-la e de todo o aprendizado de fortaleza que ela nos transmitiu até nos últimos momentos de sua vida. Hoje acreditamos que a luta é preciosa em todos os momentos, pois a partir dela nos tornamos fortes e prontos para enfrentar qualquer batalha.

Deus foi presente em todos os dias do meu cansaço que cada dia era um dia a mais vencido, ele em sua infinita misericórdia permitiu que eu aqui chegasse na sua graça e na oportunidade de cumprir mais uma etapa da minha vida.

A minha orientadora, Professora Dra. Maria de Fátima Bruno de Faria, pela atenção e compreensão quando mais precisei e todo o acompanhamento e carinho neste trabalho.

Aos meus colegas de sala, de forma especial ao meu grupo: Eliene, Elma, Letícia e Renata, pelo companheirismo nos momentos de dificuldades as quais conseguimos superar.

A todos os professores/mestres que fizeram despertar não só em mim, mas em todo o nosso grupo o valor que tem cada desafio e o que isto representa em nossos trabalhos e em nosso meio familiar.

Aos meus chefes, professores e colegas de trabalho do Departamento de Filosofia da Universidade de Brasília, pela compreensão, incentivo, contribuição para realização deste trabalho, destacando os Professores Gerson e Agnaldo e a minhas amigas Nádia e Nilda por todo o incentivo e torcida.

Em especial, agradeço as minhas queridas irmãs Eliana e Rosa, companheiras inseparáveis, que sempre me creditaram confiança, apostando que um dia eu chegaria a algum lugar de valor. 


\section{RESUMO}

Com o aumento significativo do número de Instituições de Ensino Superior no Brasil nesta última década, que permitiu a possibilidade da inserção de pessoas no ensino superior, as universidades estão tendo que conviver, cada vez mais, com um fenômeno chamado evasão. A evasão revela causas que incluem fatores sócio-econômico, cultural e familiar. $\mathrm{O}$ foco do presente trabalho recai no curso de Filosofia de uma Instituição de Ensino Público Federal, e busca identificar as principais razões que levaram vários estudantes do curso a abandonarem sua trajetória acadêmica. $O$ conceito de evasão adotado no estudo compreende somente os alunos que abandonaram os seus estudos, conforme Ristoff (1999) e Pereira (1995).Foram analisados documentos diversos da Instituição, especialmente os disponibilizados em Sistema Informatizado e pela Diretoria de Acompanhamento e Integração Acadêmica. Além disso, foram aplicados questionários para alunos que abandonaram o curso no período de 2004 a 2008, e professores em exercício do Departamento, incluindo dois coordenadores de curso. Dados oficiais da Instituição referentes aos alunos que ingressaram em 2004 revelam que 43\% abandonaram o curso de Filosofia. Os questionários evidenciaram que as principais razões da evasão no curso pesquisado se relacionam às condições socioeconômicas e interesses pessoais que dificultam conciliar estudo, trabalho e família. Para finalizar, incluem-se algumas sugestões que podem contribuir para minimizar o fenômeno da evasão.

Palavras-chave: Licenciatura/Bacharelado em Filosofia, Evasão discente, ensino superior. 


\section{LISTA DE GRÁFICOS}

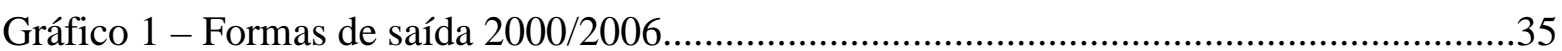

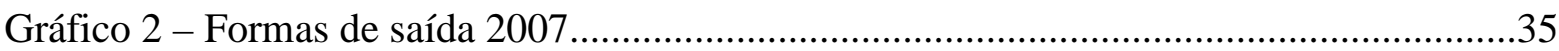




\section{LISTA DE TABELAS}

Tabela 1 - Distribuição percentual do número de Instituições de Educação Superior por Categoria Administrativa - Brasil 1995-2005

Tabela 2 - Distribuição percentual do número de ingressos pelo vestibular e por Categoria Administrativa - Brasil 1992- 2003

Tabela 3 - Distribuição de alunos, na forma de ingresso e de saída (curso Bacharelado em Filosofia)

Tabela 4 - Distribuição de alunos, na forma de ingresso e de saída (curso Licenciatura em Filosofia)

Tabela 5 - Cursos com alunos concluintes acima de $80 \%$. .35

Tabela 6 - Curso alunos concluintes abaixo de $45 \%$ .35

Tabela 7 - Motivos que levaram o aluno à escolha do curso de Filosofia .38

Tabela 8 - Desempenho dos alunos nas disciplinas básicas do curso de Filosofia. 39

Tabela 9 - Desempenho dos alunos em disciplinas de outros Institutos 39

Tabela 10 - Desempenho dos alunos em disciplinas do grupo profissional .40

Tabela 11 - Mudança no curso após ingresso do aluno. .40

Tabela 12 - Grau de satisfação do aluno com o curso de Filosofia

Tabela 13 - Fatores ligados às causas de evasão de ordem pessoal.

Tabela 14 - Causas de evasão geradas pela Instituição. 


\section{SUMÁRIO}

1 - Introdução. .11

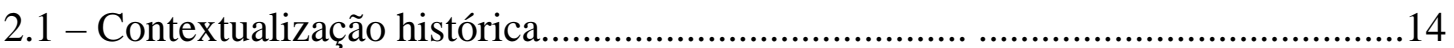

2.2 - Evasão: uma questão, política, social e institucional..........................................15

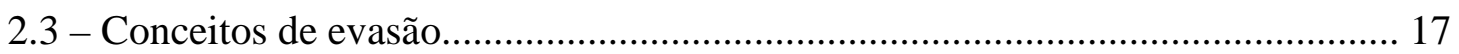

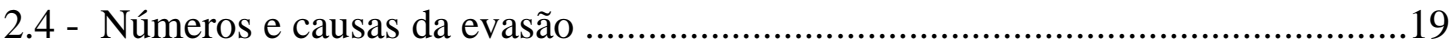

2.5 - Ações destinadas a minimizar a evasão ..............................................................22

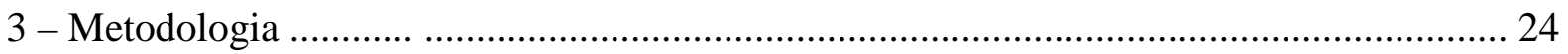

3.1 - Contextualização...................................................................................... 24

3.2 - Tipo de Pesquisa................................................................................. 25

3.3 - Participantes e amostra de documentos ........................................................ 26

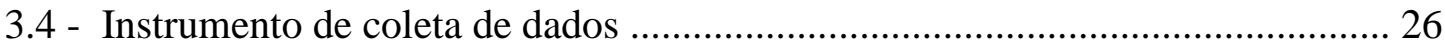

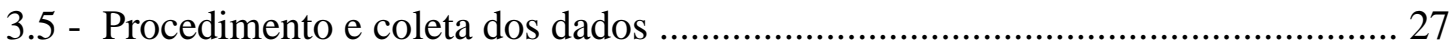

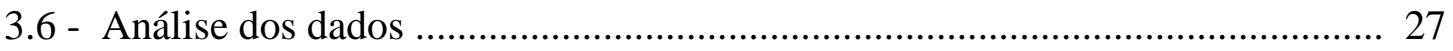

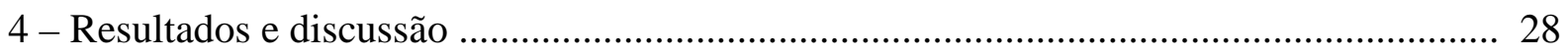

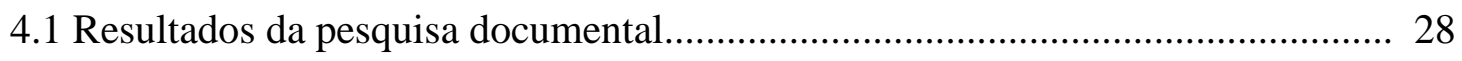

4.1.1 Caracterização dos participantes da pesquisa................................................ 38

4.1.2 Respostas dos alunos evadidos.................................................................. 38

4.1.3 Análise das respostas dos professores............................................................ 46

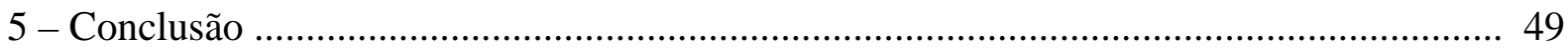

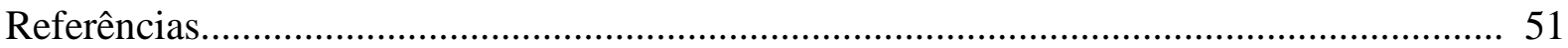




\section{INTRODUÇÃO}

Finger (1997) destaca que na administração federal indireta, representada por um conjunto de estruturas organizacionais descentralizadas, que busca uma maior flexibilidade no setor público, encontra-se a universidade pública brasileira. No entanto, esta mantém uma postura conservadora, burocrática e governamental, por isso vem resistindo aos modelos propostos de organização.

No Brasil, pode-se afirmar que, apesar das dificuldades encontradas para o gerenciamente, o ambiente educacional convencional é conservador e enfrenta dificuldades para responder às exigências do desenvolvimento socioeconômico do mundo globalizado, segundo relata Ramos (1995). Para o autor, ainda hoje, a grande maioria das universidades pratica modelos de administração autocráticos, copiados dos antigos sistemas de administração industrial, inspirados nos moldes militares, com ênfase na rigidez hierárquica, com divisão de funções centrada na ordem e obediência.

Segundo Gileno (2004), as Universidades Federais brasileiras fazem parte de uma administração pública nacional que vem passando por um período de grandes transformações. Para o autor isto é o resultado dos avanços tecnológicos, sociais, econômicos e políticos. Estes trazem consigo um modelo burocrático que vem evoluindo, mais ainda não atende as necessidades da sociedade atual.

Sendo a Universidade uma Instituição social com um alto grau de formalização, esta possui características que lhe são próprias, como: existência jurídica, a organização e funcionamento estabelecido por instrumentos, à congregação de pessoas que assumem formas e executam funções de acordo com a época, local e contexto onde se encontra inserida. A universidade tem como objetivo levar o saber, promover a cultura e trazer melhorias de vida para a sociedade (Piazza 1997 apud SILVA, 2005, p.118).

Em seus estudos, Silva (2005, p.118) considera que:

A responsabilidade fundamental da universidade é a de tornar o conhecimento (que lhe cabe conservar, organizar e produzir) acessível ao corpo social, por meio, principalmente, do ensino superior, podemos dizer que um curso de graduação é um curso de nível superior e, como tal, define-se por ser um processo de transformação do conhecimento em condutas, profissionais e pessoais, complexas, abrangentes e significativas (eficazes e relevantes) para a sociedade. 
Havia por parte das Instituições de Ensino Superior (IES) no passado certa tranquilidade quanto ao crescimento de matrículas, pois a competitividade entre as instituições públicas e privadas era menor, o que facilitava o modelo de operação utilizado entre elas. Somente a partir de 1995 o governo brasileiro passou a incentivar o setor da educação que teve uma expansão significativa, e ao mesmo tempo desconfortável, pois este não conseguiu suprir as demandas nas universidades públicas, afirma Silva (2006). Destaca o autor que "o setor de educação superior vem nos últimos anos sendo exposto a novos desafios derivados de mudanças significativas na conjuntura social e no próprio segmento educacional".

Em pesquisa o Instituto Lobo (2007) avalia que a partir desse incentivo a organização do ensino universitário brasileiro tomou um distanciamento das reais necessidades do país. As instituições privadas de ensino superior passaram a impactar de forma incisiva neste mercado sem a preocupação de capacitar o profissional que está sendo formado com responsabilidade frente ao crescimento e desenvolvimento do país.

A partir do processo educacional vigente, surge uma conduta que vêm chamando atenção não só de pesquisadores, mas de representantes governamentais, que é o fenômeno da evasão. Um conjunto de fatores pode levar o aluno ao abandono de curso e/ou a troca de curso.

Moehlecke (2004) realça em seus estudos que a evasão brasileira esta localizada no ensino básico. No entanto, quando o assunto é tratado no ensino superior a literatura se torna escassa. Pesquisas apresentam uma descrição a respeito do fenômeno por meio da identificação das características do aluno, sem antes apresentar uma análise das causas que não permitem que este permaneça na universidade. Afirma a autora que vem sendo indicados nessas pesquisas três tipos de evasão: do curso, da instituição e do sistema. Entende-se assim que cada tipo de evasão está ligado a diferentes fatores.

Neste sentido, a questão da evasão passa a ser mais bem compreendida seja por meio do enfoque institucional, representado pela universidade e/ou pela sua estrutura ou o indivíduo, representado pelo aluno que escolhe um determinado sistema.

O objetivo central deste estudo é identificar que razões levam um aluno de ensino superior do curso de Filosofia a abandonar o curso, e indicar a possibilidade de mudanças dentro do sistema (informatizado), para a manutenção do aluno no ensino superior. Para tanto, apresentam-se a seguir os objetivos específicos do estudo:

- Descrever as ações institucionais destinadas à redução da evasão na IES;

- Relacionar os percentuais de evasão no curso de Filosofia nos últimos quatro anos; 
- Relacionar os percentuais de evasão devido a desligamento por: abandono de curso, abandono voluntário e abandono por falta de rendimento acadêmico;

- Descrever as causas da evasão na percepção da Chefia do Departamento, das Coordenações e dos evadidos.

Para se entender um processo de evasão, torna-se necessário um estudo que caracterize a situação do aluno que abandona uma universidade, seja na situação de uma transferência externa ou de um desligamento do ensino superior.

Inicialmente, apresentam-se estudos a respeito da evasão a partir da análise da literatura nacional. Em seguida, é descrita a metodologia da pesquisa trazendo o histórico do departamento de Filosofia com o objetivo principal de entender as causas que levaram o aluno à evasão e os métodos e técnicas utilizados na coleta e análise dos dados. No quarto capítulo, os resultados são apresentados e discutidos. Por fim, são descritas as conclusões do estudo. 


\section{FUNDAMENTAÇÃO TEÓRICA}

Neste capítulo, discutem-se assuntos importantes para a compreensão e análise das questões que se apresentam relacionadas à evasão no ensino superior (política, social e institucional). Para tanto, faz-se necessária à definição do tema em questão e sua problemática sob a visão de alguns autores, que por sua vez discutem os possíveis motivos da evasão universitária.

\subsection{Contextualização histórica}

No Brasil, é possível identificar evasão a partir de discussões e pesquisas. O assunto tornou-se um fenômeno complexo que vem interferindo na gestão universitária seja ela pública ou privada. Estas pesquisas passaram ser mais freqüentes a partir de 1995, como resultado do "Seminário sobre evasão nas universidades brasileiras" organizado pela Secretaria de Ensino Superior (SESu) do Ministério da Educação e Cultura (MEC). Foi então proposta a criação de uma Comissão Especial de Estudos sobre Evasão nas Universidades

Públicas Brasileiras, composta por representantes das Instituições Federais de Ensino Superior (IFES) e do MEC, para fazer um estudo mais substanciado a respeito o tema, diz Moehlecke (2004).

Seguindo essa trajetória Almeida e Veloso (2002) consideram que a evasão de estudantes é um fator complicado e comum às Instituições Universitárias no mundo atual. Para os autores, este tema é objeto de análise principalmente em países de primeiro mundo, pois se trata de assunto universal e que traz certa cumplicidade de comportamentos em algumas áreas do saber, sem, no entanto, deixar de reconhecer que existem diferenças entre instituições de ensino e peculiaridades sócioeconômico e cultural em cada país.

Almeida e Veloso (2002) afirmam que existe uma democratização no Ensino Superior, e terão acesso a este aluno com diferentes níveis de desempenho no ensino médio, e de várias condições sócioeconômicas, que entre outros fatores é o que definirá a sua escolha por um curso de graduação. 
Segundo Paul e Silva (1998, p.120):

[...] o desempenho acadêmico e a intenção de trabalhar constituem variáveis de especial relevância na escolha. Com efeito, candidatos com o melhor desempenho acadêmico, independentemente de outras características, tendem a optar pelas carreiras de maior prestígio e aqueles que tencionam trabalhar apresentam a tendência a escolher carreiras que admitam a conciliação entre os estudos e o trabalho.

\subsection{Evasão: uma questão, política, social e institucional}

O Ensino Superior no Brasil, nas últimas décadas, vem se modificando no sentido do crescimento significativo de Instituições do Ensino Superior (IES) tanto do setor público quanto do privado, embora nesse último o crescimento seja muito mais amplo. Ocorre que o aumento brusco dessas IES, excepcionalmente das privadas, vem da necessidade da população brasileira em se titular, para entrar no mercado de trabalho que hoje é muito competitivo.

Segundo Gaioso (2006, p.13):

Com o significativo crescimento da iniciativa privada na educação superior brasileira, fatores econômicos ligados ao trabalho e ao estudo podem ser mais decisivos que a qualidade da integração, sendo esta, mais voltada aos países que apresentam situação econômica mais estabilizada, com iguais oportunidades de acesso e que contam com programas que garantem a permanência do aluno na educação superior.

Diante das questões vivenciadas no "mundo universitário" as desistências ocorridas poderão gerar diversos problemas tanto para as instituições, como também pra os próprios evadidos.

O Instituto Lobo (2007) pondera que a evasão estudantil no ensino superior tem uma definição universal, que vem afetar os resultados dos sistemas educacionais no Brasil. Tendo em vista que o aluno que não termina seus estudos, traz perdas sociais, acadêmicas e econômicas, esta última em especial quando se tratam de recursos públicos, e no setor privado a perda de receita é de grande importância, enfim isso envolve também o desperdício de professores, funcionários, equipamentos e espaço físico.

Percebe-se que a partir do incentivo dado pelo governo brasileiro ao setor da educação, o crescimento das instituições de ensino superior provocou uma necessidade de procedimentos administrativos e cuidados por parte do Estado em adotar medidas que poderão evitar que a evasão discente ocorra gradualmente ao longo do curso como, por exemplo, a constituição da Comissão Especial de Estudos sobre evasão pelo MEC. 
Cunha, Tunes e Silva (2001, p.262) afirmam que:

$\mathrm{Na}$ verdade, a evasão de alunos dos cursos de graduação das universidades brasileiras ainda não foi tratada com o rigor e o empenho analítico necessários ao seu entendimento. À exceção do estudo realizado recentemente por comissão instituída nacionalmente para esse fim, não se verificava, até o momento a existência de outros estudos que pudessem dar conta de um diagnóstico da evasão na graduação.

Entretanto, Moura e Silva (2007) defendem que o assunto deve ser investigado na raiz. Para os autores, a questão não deve ser considerada de forma linear para todos os sistemas, instituições e ofertas educacionais. É necessário ter claro que o afastamento definitivo de um estudante do sistema de ensino superior é fruto de múltiplos fatores: econômicos, sociais, familiares, institucionais e pessoais.

Por outro lado, Monteiro (2008) diz que a partir do momento que a evasão é detectada, torna-se fato importante que deve ser exposto ao sistema de ensino. Fato esse que poderá ser uma questão medida por um processo de avaliação do ensino em todos os níveis como necessários e fundamentais.

Nota-se, no entanto, pelo menos no Brasil, que o prolongamento de estudos não tem merecido a mesma preocupação pelos alunos, pois, para alguns prolongar sua vivência em uma universidade pública gera crescimento profissional, tendo em vista que nesse mesmo período ele faz um outro curso em uma instituição privada.

No entanto, para Almeida e Veloso (2002), tentar compreender a questão da evasão dos cursos de graduação significa poder repensar o modelo de atuação universitária perante os tantos fatores de ordem: pessoal, econômico e institucional, já identificados por vários autores: Santos (1999), Cunha (19997), Ristoff (1999), Ribeiro (2002) e tantos outros.

Para o conselheiro da Câmara de Educação Básica (CEB) do Conselho Nacional de Educação (CNE), Antonio Ibañez Ruiz, são vários os fatores que levam aos alunos a evadirem dos cursos, tais como: repetências nos primeiros anos e até mesmo a falta de recursos para que esses possam se manter.

Entende-se que há um grande desejo por parte dos alunos em terem uma titulação superior o que está ligado a uma busca de melhoria de vida e de estabilidade financeira. Gomes (1998 apud GAIOSO, 2005, p.15) diz que: 
O desejo de cursar a educação superior está intensamente vinculado a projetos de ascensão social e a bons salários. Quando esses projetos não se viabilizam na área escolhida, como é o caso do magistério, o aluno tende a abandonar o curso e vai em busca de outro mais valorizado socialmente.

Biazus (2004 apud SILVA, 2006) afirma que mesmo que se pesquise a respeito os fatores que determinam a evasão discente esta se dará em vários graus nos mais variados cursos das IES, e não haverá nenhuma lógica que possa explicar a forma com eles ocorrem no conjunto dos cursos, porque eles estão diretamente ligados às características individuais, aos fatores internos e externos as IES.

No Brasil, segundo Dal Mas Dias (1997) a evasão de estudantes pode ser considerada como uma das características da educação brasileira, por ocorrer em todos os níveis de ensino; do primeiro grau aos cursos de pós-graduação; da escolarização regular ao ensino supletivo e não-convencional. A evasão discente em cursos de graduação no Brasil apresenta um índice muito alto, cerca de 40\%, levando à hipótese de que as instituições de ensino superiores não estão se ocupando adequadamente deste fenômeno, quer na gestão dos cursos existentes, quer na abertura de novos cursos, assim informa Dal Mas Dias (1997).

Desta forma, evidencia-se a necessidade de procedimentos de apoio à administração na tomada de decisão no suporte ao planejamento estratégico institucional, definindo novas políticas que deverão ser tomadas frente às evidências encontradas no fenômeno da evasão nos cursos de graduação nas instituições de ensino superior, segundo Nassar (2004).

Paredes (1994) descreve a evasão discente a partir de dois tipos de fatores: os institucionais, ou seja, os fatores de recursos humanos, didático-pedagógicos e de infraestrutura, e como fatores pessoais aqueles relacionados a aspectos sócio-econômicos, vocacionais e a problemas pessoais. Para o autor esta é uma visão mais clara pois, na verdade, evasão é a resultante das múltiplas interações entre esses fatores. Conclui que a instituição deve se preocupar em corrigir as condições acadêmicas tentando diminuir a evasão e não interferindo nas motivações do aluno.

\subsection{Conceitos de evasão}

No Brasil, as pesquisas se tornam mais freqüentes a partir de 1995, quando foi constituída a Comissão Especial de Estudos sobre Evasão, por meio de Portaria SESu/MEC, com o objetivo de desenvolver um estudo, a respeito do desempenho das Instituições Federais de Ensino Superior. Para essa Comissão de Estudos, a referida pesquisa reuniu um conjunto 
significativo de dados de desempenho das IFES, relativos aos índices de diplomação, retenção e evasão de seus cursos de graduação identificada com objetividade, essencialmente quantitativa, tornando-se referência nacional.

Bueno (1993) concluiu a partir da análise do relatório elaborado pela Comissão Especial de Estudos sobre a Evasão nas Universidades Públicas Brasileiras (BRASIL, 1995) que a evasão é diferente de exclusão, ou seja, a primeira corresponde a uma postura ativa do aluno que decide desligar por sua própria responsabilidade, já a segunda implica a admissão de uma responsabilidade da escola e de tudo que a cerca por não ter mecanismo de aproveitamento e direcionamento do jovem que se apresenta para uma formação profissionalizante.

Ristoff (1999, p.125), por sua vez, distingue os fenômenos de mobilidade e evasão, conforme a seguir:

\begin{abstract}
...'evasão' corresponde ao abandono dos estudos, enquanto "mobilidade" corresponde ao fenômeno de migração do aluno para outro curso: parcela significativa do que chamamos evasão, no entanto, não é exclusão mas mobilidade, não é fuga, não é desperdício mas investimento, não é fracasso - nem do aluno nem do professor, nem do curso ou da Instituição - mas tentativa de buscar o sucesso ou a felicidade, aproveitando as revelações que o processo natural de crescimento do indivíduo faz sobre suas reais potencialidades.
\end{abstract}

No entanto, para Silva (2008), depois da expansão do número de matrículas verificadas a partir de 1996, e das estimativas apontadas por alguns especialistas, para o ano de 2008, onde todo este setor terá que sofrer ajustes, as IES necessitarão repensar as suas atuações no mercado. Pode-se observar no Tabela 1 a tendência, do crescimento da iniciativa privada no setor da educação, no período de 1995 a 2005.

Tabela 1 - Distribuição percentual do número de Instituições de Educação Superior, por Categoria Administrativa - Brasil 1995 - 2005

\begin{tabular}{llllll}
\hline Ano & Pública & $\%$ & Privada & $\%$ & Total \\
\hline 1995 & 210 & 23.5 & 684 & 76.5 & 894 \\
1996 & 211 & 22.9 & 711 & 77.1 & 922 \\
1997 & 211 & 23.4 & 689 & 76.6 & 900 \\
1998 & 209 & 21.5 & 764 & 78.5 & 973 \\
1999 & 192 & 17.5 & 905 & 82.5 & 1.097 \\
2000 & 176 & 14.9 & 1.004 & 85.1 & 1.180 \\
2001 & 183 & 13.2 & 1.208 & 86.8 & 1.391 \\
2002 & 195 & 11.9 & 1.442 & 88.1 & 1.637 \\
2003 & 207 & 11.1 & 1.652 & 88.9 & 1.859 \\
2004 & 219 & 10.85 & 1.801 & 89.15 & 2.020 \\
2005 & 236 & 10.21 & 2.074 & 89.79 & 2.310 \\
\hline
\end{tabular}

Fonte: MEC/INEP/CAPÉS 
Considerando os dados apresentados acima, verifica-se que houve um crescimento demasiado no ensino superior no Brasil, a partir do ano de 1995, esta expansão é maior nas instituições privadas, que representavam 76,5\% em 1995 e passaram para 89,79\%, no ano de 2005.

Ribeiro (2005) complementa que, apesar da idéia de "evasão universitária" não ser consensual como indica a Comissão Especial do MEC (BRASIL, 1995), cada estudo aborda diferentes definições para esse fenômeno, e destaca que todos eles trazem os possíveis motivos que levariam o estudante: a abandonar seu curso, a universidade ou ainda se desligar do sistema de ensino superior, ou seja, há diferentes tipos de evasão, como a seguir caracterizados.

- Evasão do curso: desligamento do curso superior em função de abandono (nãomatrícula), transferência ou reescolha, trancamento e/ou exclusão por norma institucional;

- Evasão da instituição: desligamento da instituição na qual está matriculado;

- Evasão do sistema: abandono definitivo ou temporário do ensino superior.

Neste Estudo, optou-se pelo conceito de evasão como o aluno que abandona o curso e/ou a instituição, segundo Ristoff (1999) e Pereira (1995).

\subsection{Números e causas da evasão}

Para Moehleck (2004) o perfil dos alunos evadidos, segundo pesquisa feita por NAEG/USP (1994) traz aspectos importantes a serem considerados. Para entender melhor os processos de evasão na Universidade, faz-se necessário atentar para o fato de que em alguns casos se encontram alunos que já possuem uma graduação e abandonam cursos, ou seja, o aluno não tem o mesmo compromisso nem com o curso e nem com a Instituição, pois, ele já possui conhecimentos suficientes para competir no mercado de trabalho. Isso faz com que o seu comportamento seja percebido no desenvolvimento escolar. Essa situação traduz os aspectos apontados por Oliveira e Souza (2004) que vêem um perfil novo de estudante evadido (aquele que já cursou um curso superior) seja ele por motivos de trabalho ou sócioculturais.

Também ocorre a situação na qual o aluno encontra oportunidade, seja pelo momento vivido no trabalho ou o simples fato de que um determinado curso pode fortalecer outro, do aluno abandonar o segundo curso, como exemplo: alguns alunos fazem o curso de Direito, e sentem a necessidade de completar os seus conhecimentos com o curso de Filosofia 
ou História. Esse aluno que já possui um curso superior não terá a mesma preocupação quanto ao tempo que ele levará para concluí-lo, seja ele em uma IES pública ou privada.

Um Relatório mais recente desenvolvido pelo Núcleo de Apoio aos Estudos de Graduação (NAEG) e o Centro de Estudos e Pesquisas em Políticas Publicas de Educação (CEPPPE-FEUSP, 2004) mostra que a evasão indica a dificuldade de escolha por um curso de graduação, seja por pressão familiar, ou seja, por falta de informação, e aparece como o principal motivo para a evasão $(44,5 \%)$, seguida da estrutura do curso $(30,7 \%)$, da insatisfação com o mercado de trabalho da profissão escolhida $(13,4 \%)$ e de razões pessoais (11.4\%), resultados mostrados por Ribeiro (2005).

Segundo Moehlecke (2004), os motivos alegados pelos autores aqui citados, para a evasão, podem ser agrupados em três grandes grupos: a) aqueles que se relacionam ao próprio estudante e suas escolhas; b) os relacionados ao curso e/ou à instituição; c) os relacionados a fatores sócio-culturais e econômicos externos.

Na grande parte das pesquisas a respeito de evasão, considera-se que esta é gerada a partir de vários fatores e uma possível solução para se entender este fenômeno é a relação existente entre as causas internas e externas, apontadas por Paredes (1994).

Entre outras causas, Ribeiro (2005) mostra que as principais pesquisas que tiveram início após 1985 revelam que a evasão universitária, tem sido de ordem: financeira; de ajustamento ao curso e/ou universidade escolhida; educacional (déficits no ensino fundamental e médio que complicam o aproveitamento e o desenvolvimento do aluno) ou de dedicação (aluno-trabalhador).

Segundo Almeida e Veloso (2002) é impossível conciliar estudo e trabalho. Consideram que a indecisão na escolha por desconhecimento dos cursos e a formação no ensino médio de baixa qualidade são fatores primordiais na causa da evasão universitária.

No entanto, Paredes (1994) aponta possíveis causas que podem ser separadas em dois grupos:

(1) Causas internas à universidade, ou seja, o aluno desistiria do curso em função de discordância ou descontentamento acerca do método didático pedagógico, do corpo docente e/ou da infra-estrutura universitária;

(2) Causas externas à universidade mais vinculadas ao aluno como dificuldade de adaptação ao ambiente universitário, problemas financeiros, curso escolhido não era o que aluno esperava e/ou problemas de ordem pessoal das mais variadas espécies (mudanças de residência, doenças, problemas familiares, conjugais e/ou psicológicos). 
Para Machado, Melo Filho e Pinto (2005), os problemas responsáveis pela evasão são: desconhecimento do curso e/ou carreira, falta de apoio para poder estudar e trabalhar simultaneamente e situação financeira familiar ruim. Cunha, Tunes e Silva (2001), por sua vez, mostram que o desamparo e a falta de informação na chegada ao curso, o despreparo do aluno para lidar com o sistema universitário e a impossibilidade de estabelecer vínculos pessoais significativos, são fatores que levam à evasão. Enquanto que Lehman (2005) aponta a escolha precoce e carente de informações relativas o curso e Silva (1994) vê nas escolhas desarticuladas (escolha de vários cursos ao mesmo tempo), fator principal capaz de desencadear o processo de evasão em questão.

O Sindicato das Entidades Mantenedoras de Estabelecimentos de Ensino Superior no Estado de São Paulo (SEMESP), instituição responsável por pesquisas nas instituições de ensino superior privadas, ressalta que as dificuldades financeiras são a principal causa da evasão neste setor. Percebe-se nesta questão que ação econômica é mais valorosa do que a ação social (SEMESP, 2008).

Almeida e Veloso (2002) apontam que em um processo educacional é necessário que se entenda o início que se dá com a entrada do aluno na Instituição e o momento de sua saída que é a sua formatura. No entanto, vários fatos podem ocorre neste percurso: sucessos por esforços desenvolvidos, obstáculos que surgem de acordo com sua trajetória que podem acabar interferindo no processo, ocasionando assim o seu afastamento da instituição ou do curso, que irá traduzir em uma evasão no processo educacional.

Vários estudos identificam o crescimento das IES, o que dificulta ao aluno a escolha por um curso de graduação. Observa-se que o número de ingressantes é maior do que aqueles que são titulados, ou seja, o aluno se matricula, tanto na pública como na privada, mas não conclui o seu curso.

Na Tabela 2, destaca-se o crescimento das IES privadas que tiveram um aumento significativo em números de alunos no período que vai de 1992 a 2003, passando de 63,6\% a $78,6 \%$ segundo dados do INEP (2005). 
Tabela 2 - Distribuição percentual do número de ingressos pelo vestibular e por categoria administrativa Brasil 1992-2003

\begin{tabular}{lccccc}
\hline \multirow{2}{*}{ Ano } & Pública & $\%$ & Privada & $\%$ & Total \\
& & & & & \\
\hline 1992 & 149.726 & 36.4 & 261.184 & 63.6 & 410.910 \\
1994 & 159.786 & 34.5 & 303.454 & 65.5 & 463.240 \\
1996 & 166.494 & 32.4 & 347.348 & 67.6 & 513.842 \\
1998 & 196.365 & 30.1 & 454.988 & 69.9 & 651.353 \\
2000 & 227.157 & 27.4 & 602.549 & 72.6 & 829.706 \\
2002 & 251.066 & 22.9 & 844.620 & 77.1 & 1.095 .686 \\
2003 & 249.002 & 21.4 & 914.840 & 78.6 & 1.163 .842 \\
\hline \multicolumn{7}{c}{ Fonte: MEC/INEP/CAPÉS }
\end{tabular}

Todavia observa-se que houve também um crescimento nas Instituições públicas, conforme mostra a Tabela 2, porém a participação na parcela de alunos atendidos diminuiu.

\subsection{Ação destinada a minimizar a evasão}

A idéia principal apontada por Almeida e Veloso (2002) é que a Instituição de Ensino Superior representa um conjunto complexo de recursos variados cujos objetivos últimos são a geração de conhecimento e a educação. E que os processos envolvidos a fim de atingir esses objetivos são muitos, e de complexidade variável, sendo necessários procedimentos sistemáticos de gerenciamento e controle especializados para que os fins propostos sejam efetivamente atingidos.

Para Catapan (2001), na proposta educacional deve-se considerar três dimensões básicas tratadas como planos: a concepção pedagógica como plano de eminência; a organização de pessoas como plano de gestão e, finalmente, a base de informática como plano infra, ou seja, a base informatizada é um fator determinante no processo de gestão educacional, definindo ritmo, qualidade, precisão e efetividade do processo.

Assim, Nassar (2004) vem sugerir a gestão acadêmica, com o intuito de diminuir as taxas de evasão, podendo realizar uma avaliação continuada identificando os inúmeros fatores implicativos e propor ações não só de prevenção da evasão mais da promoção de formação, que, segundo o autor, responde melhor à expectativa dos discentes.

De acordo com as informações apresentadas pelo Instituto Nacional de Pesquisa (INEP), busca-se entender ainda mais o fenômeno da evasão universitária, considerando ser necessário estudar a situação da evasão com pessoas que já passaram por esse processo e compreender as implicações causadas na vida pessoal desses estudantes universitários. A partir desses entendimentos e conceitos, convém saber quais os fatores que interferem na 
evasão de alunos matriculados em um determinado curso de uma Instituição de Ensino Público Superior (IFES). Assim, pretende-se contribuir de forma significativa à sociedade por meio de dados que revelem um dos desafios existentes na educação superior brasileira.

Quando se apresentam números reais, retirados de censos a respeito da a educação, percebe-se que a situação brasileira se agrava e caminha para proporções maiores com grandes desperdícios de professores, equipamentos e espaço físico.

Para Almeida e Veloso (2002), atingir metas em relação a evasão significa construir um sistema onde por meio de análises de variáveis seja possível identificar e compreender os fatores que interferem neste fenômeno, como por exemplo: monitorar de formar precisa, com o uso de sistemas de informática, a saída do aluno.

A partir dessa análise da situação e das variáveis nela envolvidas que se poderá tomar decisões mais precisas para a realização das metas, como indicam Almeida e Veloso (2002).

Como lembra Ristoff (1999), parte da evasão que habitualmente é contabilizada pode significar apenas mobilidade estudantil, que não é necessariamente ruim, pois reflete mudanças de curso numa mesma instituição ou transferências para outra instituição, freqüentemente relacionada à insatisfação dos alunos com os cursos que seguiam, conduzindo-os à busca de uma nova carreira.

Para Velloso e Cardoso (2002,) a mobilidade também tem outra faceta, embora menos freqüente. Em algumas IES um aluno pode ter mais de uma matrícula, ou seja, ele pode fazer a opção seguindo dois cursos distintos e, a desistência de um deles corresponde de fato à mobilidade estudantil, mas não à evasão propriamente dita, embora em várias IES essa desistência seja contabilizada nas taxas de abandono.

Para Paredes (1994), a evasão discente diz respeito ao abandono definitivo da formação em nível superior, o autor também assinala que os dados relativos o fenômeno costumam ser superestimados.

Em pesquisa realizada pelo Instituto Lobo (2007), no país, a média das taxas de abandono no período de 2000 a 2005 foi de 22\%. Já quando as estimativas são feitas para subconjuntos do sistema - forma de organização acadêmica (universidades, centros universitários e faculdades) ou por categoria administrativa da IES, por exemplo - os índices estimados inevitavelmente incluem um componente de mobilidade estudantil, embora menor do que as taxas calculadas separadamente para cada curso, como habitualmente se faz. 


\section{METODOLOGIA}

Para se alcançar o objetivo delineado, foram realizados pesquisa documental por meio de questionários. Este trabalho foi constituído em duas etapas, a saber: a do levantamento da trajetória acadêmica de ex-alunos do curso de Filosofia - desde o ingresso por vestibular à saída antes do término do curso - e outra, dos questionários enviados aos exalunos, a professores em exercício no departamento de Filosofia e aos coordenadores do curso de graduação e de pós-graduação e a chefia. O período de abrangência da pesquisa compreendeu o intervalo de tempo do primeiro período do $1^{\circ}$ semestre de 2004 ao $2^{\circ}$ semestre de 2008.

\subsection{Contextualização}

Alguns autores como Nassar (2004) e Dal Mas Dias (1997) consideram que o tema evasão é uma característica da educação brasileira, e que após incentivo do governo o processo da educação teve uma grande expansão para a iniciativa privada. No entanto, Almeida e Veloso (2002) entendem que o processo da evasão está ligado ao modelo de atuação das instituições e a alguns fatores, tais como: aspectos sócio-econômicos, familiares e trabalho.

Paredes (1994) evidencia que os fatores citados por Almeida e Veloso (2002) caracterizam-se como uma divisão, onde cada fator tem a sua própria consequência, mas na realidade se trata de um fenômeno complexo que pode ressaltar em várias interações entre esses fatores (internos e externos).

Neste estudo, considerou-se evasão todo registro de saída de aluno constante do Sistema de Graduação (SIGRA) da Secretaria de Administração Acadêmica (SAA), da Universidade pesquisada, que não seja pela diplomação, por falecimento, por transferência para outro curso na mesma Instituição ou opção por dupla habilitação. Optou-se assim pelo conceito de evasão como "abandono dos estudos”, de acordo com Ristoff (1999, p.125).

Tais discrepâncias entre o que é evasão para Paredes (1994) e Ristoff (1999) e o que a Instituição pesquisada considera, são compreendidas a partir do que Ribeiro (2005) mostra, de que a idéia de evasão universitária não é consensual, pois cada estudo aborda diferentes definições. Mas destaca o autor que todos eles trazem possíveis motivos que levariam o estudante a: abandonar o curso, a universidade ou ainda se desligar do sistema de ensino superior. 
Para a Diretoria de Acompanhamento e Integração Acadêmica da Universidade (DAIA), diminuir as taxas de evasão no ensino superior de 50\% para 10\% até 2012 é uma das principais metas do Programa de Apoio a Planos de Reestruturação das Universidades Federais (REUNI). Proposto pelo Ministério da Educação (MEC), o REUNI foi assinado, em março de 2008, por todas as universidades federais brasileiras, que começam a se preparar para atingir as metas sugeridas pelo programa. De acordo com o MEC (2008).

\begin{abstract}
Ao liberar um volume de recursos dessa natureza (o REUNI vai investir cerca de cinco bilhões de reais), é uma obrigação do governo federal criar mecanismos que assegurem o bom uso do dinheiro e os fins a que os recursos se destinam a Diretora de Desenvolvimento da Rede de Instituições Federais de Ensino Superior (IFES) do Ministério da Educação (MEC,2008).
\end{abstract}

A partir de análises feitas na Legislação vigente na Universidade que caracteriza e regulamenta o fenômeno da evasão, percebe-se que o termo exclusão caracteriza a saída do aluno da Instituição sem concluir o curso de graduação. Dentro desta norma interna da Universidade, pode-se refletir a partir de Bueno (1993) que a responsabilidade pelo processo é da Instituição. Para o autor, evasão distingue-se de "exclusão". A primeira corresponde "a uma postura ativa do aluno que decide desligar-se por sua própria responsabilidade", já a segunda "implica a admissão de uma responsabilidade da escola e de tudo que a cerca por não ter mecanismos de aproveitamento e direcionamento do jovem que se apresenta para uma formação profissionalizante" (BUENO, 1993, p.35).

Para melhor compreender as características do curso em que se pesquisou a evasão, foram analisados documentos do Departamento de Filosofia da Universidade e constatou-se que a criação do mesmo ocorreu em maio de 1986. Com a criação da Universidade, em 1962, um "Setor de Filosofia", foi instituído na unidade do Instituto Central de Ciências Humanas, que contava com um grupo de docentes que oferecia disciplinas filosóficas. Esse grupo de professores estava administrativamente vinculado ao Departamento de Geografia e História (GEH). No Centro de Estudos Clássicos da Universidade também foram oferecidos cursos e desenvolvidas outras atividades de interesse filosófico, ligadas especialmente ao pensamento grego clássico. Um curso de graduação em Filosofia funcionou regularmente, nos meados dos anos 60 até 1972, quando se suspendeu o correspondente vestibular, por decisão da reitoria. Antes de sua reativação, algumas disciplinas filosóficas eram oferecidas, sobretudo para alunos de outras áreas pelo GEH, e que constituiu o núcleo de professores que viria a compor o atual Departamento de Filosofia (FIL). O curso foi restaurado e regularizado em 1984, com as habilitações em bacharelado (que visa à formação estritamente acadêmica do aluno) e licenciatura (voltada também para a formação de 
professores de ensino fundamental e médio). É importante ressaltar que somente a partir de 1986 o Curso de Filosofia foi separado do GEH, e teve sua criação pela Universidade.

O Programa de Mestrado em Filosofia teve início em março de 2000.

Atualmente o Departamento de Filosofia conta com dezessete docentes do quadro com dedicação exclusiva e doutores em sua titulação, e mais três docentes Substitutos, aproximadamente 230 alunos de graduação e 37 alunos do curso de mestrado.

Em 1988, o curso passou por uma reforma curricular, seguindo a reestruturação geral dos cursos de graduação da Universidade, e a outra aconteceu em 1994, que estabeleceu a estrutura em vigor atualmente.

Vale ressaltar que as disciplinas oferecidas pelo departamento de Filosofia atendem não somente o curso de Filosofia, mas também a tantos outros dentro da universidade como exemplo: Direito, Psicologia, Pedagogia, Letras, História, Geografia, Ciências Políticas e Biologia. Essas disciplinas oferecidas para o curso de Filosofia dividemse em: obrigatórias e obrigatórias seletivas. Também são obrigatórias para licenciatura algumas disciplinas oferecidas pela Faculdade de Educação e pelo Instituto de Psicologia. Enquanto que, para os demais cursos da referida Universidade, elas estão divididas em: optativas e livres.

Este Departamento oferece atividades como monitorias, bolsas de estudos, estudos em laboratório e atividades de extensão.

\subsection{Tipo de Pesquisa}

Foi realizada pesquisa quantitativa com emprego das técnicas de pesquisa documental e levantamento de dados (survey). Utilizou-se a análise de documentos para complementar as informações recebidas das outras fontes e para comparar com o levantamento de dados. Conforme consideram Ludke e André (1986, p.38), a pesquisa documental "pode se constituir uma técnica valiosa de abordagem obtida por técnicas, seja desvelando aspectos novos de um tema ou problema”.

\subsection{Participantes da pesquisa e amostra de documentos}

Foram incluídos no estudo da evasão alunos que ingressaram no curso por intermédio de concurso vestibular (20 vagas), transferência obrigatória, transferência 
facultativa, convênio, programa de avaliação seriada (20 vagas), dupla habilitação, mudança de curso e acordo cultural (PEC), a partir do primeiro semestre de 2004.

No período compreendido entre o primeiro semestre de 2004 e o segundo semestre de 2008 evadiram-se do curso de Filosofia 24 alunos, o que representa a população de estudos em relação aos alunos. Desses, apenas cinco responderam ao questionário enviado por e-mail e pelos Correios.

Em relação aos professores do curso, dos 17 vinculados ao Departamento, 12 participaram da pesquisa. Desses, um desempenhava também a função de coordenador do curso de graduação, o outro a coordenação do curso de pós-graduação em Filosofia e um a função de chefe.

Em relação à pesquisa documental, foram extraídos do SIGRA dados relativos a: o tipo de ingresso na Universidade (vestibular, programa de avaliação seriada, transferência obrigatória, transferência facultativa, convênio, dupla habilitação, mudança de curso e acordo cultural) e as formas de saídas (formatura, desligamento voluntário, desligamento por abandono, desligamento por não terem cumprido a condição exigida pelo curso e desligamento por força de convênio).

\subsection{Instrumento de coleta de dados}

Foi utilizado como instrumento de coleta de dados questionário semelhante ao já utilizado pelo Instituto de Física (em 2008) e o Instituto de Química (em 2001), da mesma Universidade. No entanto, foram feitos alguns ajustes, para que se pudesse melhor compreender os fatores que levaram o aluno à desistência do curso de Filosofia. Assim o questionário aplicado junto aos alunos incluiu questões relacionadas à forma de seu ingresso, ao seu desempenho no curso durante o seu período na Instituição, dentre outras (vide Apêndice A).

O questionário oferecido aos professores, às coordenações e à chefia, foi elaborado pela autora da pesquisa e continha itens referentes à sua opinião quanto às principais causas de evasão no curso, assim como também o que poderia ser realizado para que se reduzisse a evasão (vide Apêndice B). 


\subsection{Procedimentos de coleta dos dados}

Os participantes foram selecionados a partir de pesquisa feita no Sistema de Graduação, nas páginas de Acompanhamento de aluno - ALUREL, em Planejamento - Curso - CUREVA e Ingresso - DADPES. Assim, todos os alunos evadidos entre 2004 e 2008 foram contatados por e-mail, a fim de verificar a possibilidade de participarem da pesquisa e, posteriormente, os questionários foram enviados pelos Correios.

O e-mail enviado descrevia o objetivo da pesquisa e convidava os alunos a participarem. Dos 24 alunos apenas cinco alunos responderam o e-mail.

Aos docentes o questionário foi enviado por e-mail e também disponibilizado impresso em seus escaninhos. Foi estipulado o prazo de 15 dias para devolução dos questionários, tanto para os ex-alunos quanto para os docentes, a contar o dia da postagem dos mesmos (no caso dos alunos) nos Correios e o envio do $e$-mail (para os docentes).

\subsection{Análise dos dados}

Os dados extraídos dos documentos e das respostas aos questionários foram expressos em tabelas e gráficos contendo freqüências. 


\section{RESULTADOS E DISCUSSÃO}

O presente estudo fundamentou-se em conceitos explicitados por Ristoff (1999) e Pereira (1995). Assim o critério adotado para avaliar o índice de evasão no curso baseou-se na concepção desses autores para quem a evasão abrange somente os alunos que abandonaram os seus estudos. A partir destes dados foi possível identificar junto ao SIGRA, durante os dez semestres que se seguiram até a formatura da turma que entrou em 2004, quantos e de que formas os alunos saíram do sistema de ensino.

Este capítulo está organizado da seguinte forma: inicialmente, são apresentados os resultados da pesquisa documental, em seguida as respostas dos questionários aplicados juntos aos alunos evadidos e, por fim, as respostas dos professores, coordenações e chefia que participaram da pesquisa.

\subsection{Resultados da pesquisa documental}

Quando se coloca em questão a evasão escolar nos cursos de licenciatura e bacharelado depara-se com uma situação preocupante, ou seja, a que o aluno evadido tem sido pouco ouvido quanto o assunto. Uma das razões que explica tal situação é a dificuldade de localizá-lo, após sua saída da Instituição, pois, os dados pessoais encontrados nos sistemas da Instituição estão desatualizados; outro motivo é devido ao fato de que uma vez que esses estudantes já se afastaram da Instituição, assim considerando-se que o estudante evadido segundo Ristoff (1999) e Pereira (1995) é aquele que abandona o curso e/ou a instituição, não manifestam interesse em colaborar com qualquer tipo de estudo que esteja sendo feito a respeito do assunto. Neste estudo, a opção foi ouvir o aluno evadido do curso de licenciatura/bacharelado em Filosofia de uma Universidade Pública Federal, com o intuito de captar as suas impressões e representações sobre a Universidade, o curso que freqüentou, ciente das dificuldades mencionadas.

Neste sentido optou-se por resgatar da memória do estudante evadido a construção histórica da evasão escolar, segundo Cunha (1998, p.126):

O sistema social conscientemente envolve as pessoas numa espiral de ação sem reflexão. Fazemos as coisas porque todos fazem, porque nos disseram que assim é que se age, porque a mídia estimula e os padrões sociais aplaudem. Acabamos agindo sobre o ponto de vista do outro, abrindo mão da nossa própria identidade, da nossa liberdade de ver e agir sobre o mundo, da nossa capacidade de entender e significar por nós mesmos. 
Atualmente, o acesso à Universidade ocorre por meio de dois processos seletivos diferentes: o Vestibular processo mais tradicional e o Programa de Avaliação e Seleção (PAS). O número de vagas oferecidas para cada processo seletivo tem sido de dez por semestre, perfazendo um total de quarenta vagas anuais. Por meio do sistema informatizado da Universidade, foi também possível acessar a tela chamada demonstrativo de evasão de alunos de graduação, nas opções código 3366 (bacharelado) e código 3344 (licenciatura).

Das turmas que iniciaram em 2004 até o segundo semestre de 2008 no bacharelado (Tabela 3), encontram-se 49 alunos evadidos. Enquanto que, no mesmo período, a licenciatura (Tabela 4) teve um número de 38 alunos evadidos.

$\mathrm{Na}$ página a seguir, encontram-se tabelas demonstrativas quanto à forma de entrada e saída dos discentes no período do primeiro semestre de 2004 ao segundo semestre de 2008 do curso de Filosofia.

Vale ressaltar que foram considerados nas Tabelas 3 e 4 os alunos desligados por meio de: Desligamento Voluntário (DVO), Desligamento Abandono (DAB), Desligamento não cumpriu Condição (DNC) e Desligamento Força de Convênio (DFC). Onde além desses registros encontram-se também as saídas por formatura (FOR).

Tabela 3 - Distribuição de alunos, na forma de ingresso e de saída (curso Bacharelado em Filosofia)

\begin{tabular}{|c|c|c|c|c|c|c|}
\hline $\begin{array}{l}\text { FORMA DE } \\
\text { INGRESSO }\end{array}$ & $\begin{array}{l}\mathrm{N}^{\circ} \mathrm{DE} \\
\text { ALUNOS }\end{array}$ & & & $\begin{array}{l}\text { FORMAS } \\
\text { DE } \\
\text { SAÍDAS }\end{array}$ & & \\
\hline & & FOR & DFC & DVO & DAB & DNC \\
\hline VESTIBULAR & 67 & 6 & & 2 & 16 & 13 \\
\hline TRANSF.OBRIGATÓRIA & 2 & & & & 1 & \\
\hline TRANSF.FACULTATIVA & 1 & & & & 1 & \\
\hline CONVENIO & 1 & & & & & 1 \\
\hline MUDANÇA DE CURSO & 3 & & & & & \\
\hline ACORDO CULTURAL & 1 & 1 & & 1 & 1 & \\
\hline PROG. DE AVALIAÇÃO SERIADA & 19 & 3 & & 2 & 2 & 4 \\
\hline DUPLA HABILITAÇÃO & 21 & 5 & 2 & & & 2 \\
\hline CONVÊNIO & 3 & & & & 1 & \\
\hline TOTAL & 118 & 15 & 2 & 5 & 19 & 23 \\
\hline
\end{tabular}

FONTE SIGRA/Universidade - 2004/2008 
Legenda:

Ingresso

VEST - Vestibular

TFO - Transferência Obrigatória

TFF - Transferência Facultativa

CON - Convênio

PAS - Programa de avaliação seriada

DHA - Dupla Habilitação

MUC - Mudança de curso

ACC - Acordo cultural - PEC
Forma de saída

FOR - Formatura

DVO - Desligamento voluntário

DAB - Desligamento abandono

DNC - Desligamento (não cumpriu con dição)

DFC - Desligamento força de convênio

Na Tabela 3 encontram-se no período de 2004 a 2008 todas as formas de ingressos oferecidas pelo curso de Filosofia na opção bacharelado. Percebe-se que o número de alunos matriculados é superior ao de alunos concluintes (formatura) que representa em torno de $12 \%$. Percebe-se ainda que as demais formas de saídas superam a de alunos concluintes. Dentro do conceito estudado que a evasão é o abandono do curso, foi encontrado o número de 49 alunos evadidos, pois foram incluídos os que saíram por Desligamento Voluntário (DVO), por Desligamento Abandono (DAB), os alunos que não registraram matrícula por períodos consecutivos ou não conseguiram cumprir as condições exigidas pelo curso (DNC), o aluno que não cursou quatro disciplinas com aprovação em dois períodos consecutivos, e ainda o Desligamento por força de Convênio (DFC).

$\mathrm{Na}$ Tabela 4, encontram-se os dados relativos ao curso de Licenciatura.

Tabela 4 - Distribuição de alunos, na forma de ingresso e de saída (curso Licenciatura em Filosofia)

\begin{tabular}{l|c|c|c|c|c}
\hline $\begin{array}{l}\text { FORMA DE } \\
\text { INGRESSO }\end{array}$ & $\begin{array}{c}\mathrm{N}^{\circ} \text { DE } \\
\text { ALUNOS }\end{array}$ & & & $\begin{array}{l}\text { FORMAS DE } \\
\text { SAÍDAS }\end{array}$ & \\
\hline VESTIBULAR & & FOR & DVO & DAB & DNC \\
\hline TRANSF.OBRIGATÓRIA & 1 & & 4 & 4 & 11 \\
\hline TRANSF.FACULTATIVA & 6 & & & & \\
\hline CONVENIO & 1 & & 1 & & \\
\hline $\begin{array}{l}\text { PROG. DE AVALIAÇÃO } \\
\text { SERIADA }\end{array}$ & 19 & & & 5 & 4 \\
\hline DUPLA HABILITAÇÃO & 55 & 19 & & 3 & 6 \\
\hline TOTAL & 118 & 19 & 5 & 12 & 21
\end{tabular}

FONTE SIGRA/Universidade - 2004/2008

Legenda:

Ingresso

VEST - Vestibular

TFO - Transferência Obrigatória

TFF - Transferência Facultativa

CON - Convênio

PAS - Programa de avaliação seriada

DHA - Dupla Habilitação

MUC - Mudança de curso

ACC - Acordo cultural - PEC
Forma de saída

FOR - Formatura

DVO - Desligamento voluntário

DAB - Desligamento abandono

DNC - Desligamento (não cumpriu con dição) 
Conforme Tabela 4, também elaborada com base no SIGRA, encontram-se no mesmo período formas de ingressos oferecidas pelo curso de Filosofia na opção licenciatura, com o mesmo número de matrículas que do bacharelado (Tabela 3) e dentre as formas de saídas o número de concluintes (formatura) é de 19 alunos. Foram incluídos por Desligamento por Abandono (DAB) 12 alunos, por Desligamento Voluntário (DVO) 5 alunos e por Desligamento por não ter cumprido as Condições exigidas pelo curso (DNC) 21 alunos. Percebe-se que o número de concluintes na licenciatura supera o de concluintes no bacharelado.

Constatou-se ainda em pesquisa no SIGRA/SAA com referência à Tabela 4 que o total de alunos evadidos por DNC, DAB e DVO somam um total de 38 alunos evadidos.

Cabe ressaltar que 22 alunos retornaram à Instituição por meio do sistema de reintegração, ou seja, o processo em que o aluno expõe os motivos que o levou a abandonar e/ou não cumprir as condições de cursar o mínimo de créditos exigidos no curso pela Instituição. A partir daí o seu recurso é analisado por uma comissão de Acompanhamento e Integração Acadêmica da Universidade (CAO), constituída por professores, psicólogos, Diretora da Diretoria de Acompanhamento e Integração Acadêmica (DAIA) e o Secretário de Administração Acadêmica que após análise emitem parecer que é julgado pelo Colegiado de Graduação (CEG) e Decanato de Graduação (DEG). Dado parecer favorável este terá que cumprir plano de estudos construído pelo coordenador do curso, onde constará o período e o número de créditos que o estudante deverá cumprir para a conclusão de seu curso. Vale lembrar que o período e o número de créditos devem estar de acordo com o Projeto Pedagógico do Curso. Estas instruções fazem parte da legislação vigente na Universidade, constante nas: Instrução do Decanato de Ensino de Graduação no 01/2007; Resolução do Decanato de Ensino de Graduação no 03/2006; Resolução do Decanato de Ensino de Graduação n 001/2007; Resolução do Conselho de Ensino, Pesquisa e Extensão nº 038/94; Resolução do Conselho de Ensino, Pesquisa e Extensão nº 039/04; Resolução do Conselho de Ensino, Pesquisa e Extensão nº 041/04.

Nas Tabelas 3 e 4, a evasão foi apresentada conforme registro estabelecido pelo SIGRA no curso de Filosofia da Universidade, que considera evasão todo o tipo de desligamento constante em legislação interna vigente, ou seja, é fundamentalmente pelo Não Cumprimento da Condição exigida pelo Curso (DNC), o aluno não cumpriu o mínimo de créditos exigidos pelo curso por dois períodos consecutivos; por Desligamento por 
Abandono (DAB), o aluno por algum motivo não registrou matricula em dois períodos consecutivos; por Desligamento Força de Convênio (DFC), não houve cumprimento do prazo pelo aluno para cursar as disciplinas e, por fim, por Desligamento Voluntário (DVO), o aluno justifica a Instituição a sua decisão em abandonar o curso.

Ainda em pesquisa no SIGRA, contatou-se que no curso de bacharelado em Filosofia o ingresso foi de 118 alunos e apenas 53 estão estudando. E no curso de licenciatura o ingresso foi de 182 e 122 estão estudando. Esses dados são referentes ao período de 2004 a 2008.

Seguindo as bases da SAA, o total de alunos que ingressaram no curso de Filosofia nas opções bacharelado/licenciatura de 2004 a 2008 é de 300 alunos, sendo que apenas 175 estão ativos, ou seja, realizando os seus cursos.

Para o sistema utilizado pela Universidade, os alunos considerados desligados por meio de: Desligamento por Abandono (DAB) e Desligamento por não terem cumprido condição (DNC) são alunos evadidos. Mas, na realidade, eles não se evadiram do curso, conforme considera o SIGRA, pois fizeram a opção por Dupla Habilitação (DHA) que é a modalidade oferecida pela Universidade que dá direito ao aluno cursar as opções de bacharelado e licenciatura ao mesmo tempo, e não conseguindo atingir os créditos necessários para formar nas duas habilitações, o aluno faz a escolha por uma habilitação apenas, sendo que a outra fica abandonada e é considerada no referido sistema como evasão.

Vale ressaltar que durante esta pesquisa foi detectado nas bases dos sistemas informatizados da Universidade que todos os alunos considerados evadidos da instituição, ou seja, que abandonaram o curso não retornaram. E cerca de $40 \%$ dos alunos pedem reintegração (a reintegração significa a retomada do aluno ao sistema da Universidade, após aprovação de plano de estudo pela Coordenação do curso, DAIA e CEG).

Neste estudo, foi considerado o conceito adotado por Paredes (1994) e Ristoff (1999) de que evasão se caracteriza como abandono de curso, mas, no entanto, por meio da análise dos documentos pesquisados na Instituição, constatou-se que são consideradas todas as formas de saída da Universidade como evasão. Nesse caso, não se faz distinção entre mobilidade estudantil e evasão, também descrita por Ristoff (1999, p. 125) que diferencia um fenômeno do outro, pois "evasão, corresponde ao abandono dos estudos, enquanto mobilidade corresponde à migração do aluno para outro curso".

Constam 87 alunos evadidos no SIGRA, mas a partir do conceito adotado na pesquisa foi possível perceber que no período de 2004 a 2008 nas opções do curso que 
oferece: bacharelado e licenciatura, o número de alunos evadidos na verdade foi de 46, pois, foram desligados da Instituição por terem deixado de cumprir as condições exigidas pelo curso (DNC), não cursando disciplinas exigidas em dois períodos consecutivos ou não registraram matrícula em dois períodos consecutivos (DAB). Desses, 22 alunos solicitaram reintegração, e apenas 24 alunos estão realmente afastados da Instituição, restando 41 alunos que estão na mobilidade estudantil. A Universidade oferece a opção por dupla habilitação, que são os alunos que cursavam disciplinas do bacharelado e da licenciatura, e não conseguindo cumprir o número de créditos exigidos pelo curso para umas das opções, tiveram que abandonar uma delas, e assim foram considerados pelo sistema como evadidos.

Considerando o conceito adotado por Velloso e Cardoso (2002) que mostra a mobilidade estudantil como máscaras usadas por algumas Instituições de ensino superior, ou seja, o aluno pode ter mais de uma matrícula, seguindo dois cursos distintos e até mesmo a desistência de um deles, o que corresponde à mobilidade estudantil e não evasão, embora para algumas Instituições essa desistência seja contabilizada como taxa de abandono, confirma-se assim que este é o conceito adotado pela Universidade onde esta sendo feito o estudo.

Segundo a DAIA, baseando-se em uma pesquisa inédita que avalia a forma como os universitários vêm deixando o ensino superior durante um período de seis anos a Universidade, cuja taxa de conclusão de curso está em torno de 62\% entre 2001 a 2006 (porcentagem equiparada à média nacional), estão sendo elaborados metas e estratégias para que a Universidade possa alcançar o quanto antes um nível irrisório de evasão.

Esclarece que dentre tantos projetos da Universidade, está inclusa a redistribuição de vagas identificadas a cada semestre a outros estudantes. Promete também que além desta distribuição de vagas, a Universidade estará mais atenta ao desempenho dos alunos, pois dos 269 universitários que abandonaram os estudos na universidade no ano de 2007, cerca de $44 \%$ o fizeram porque tinham dificuldades para seguir o conteúdo das disciplinas. Baseado nestes dados, o Decanato de Graduação (DEG) e a DAIA lançaram o Manual de Orientação Acadêmica para o Professor de Graduação ou da Orientação ao Orientador.

Nos Gráficos 1 e 2 podem ser visualizadas as formas de saídas dos alunos no período de 2001 a 2006 
Gráfico 1

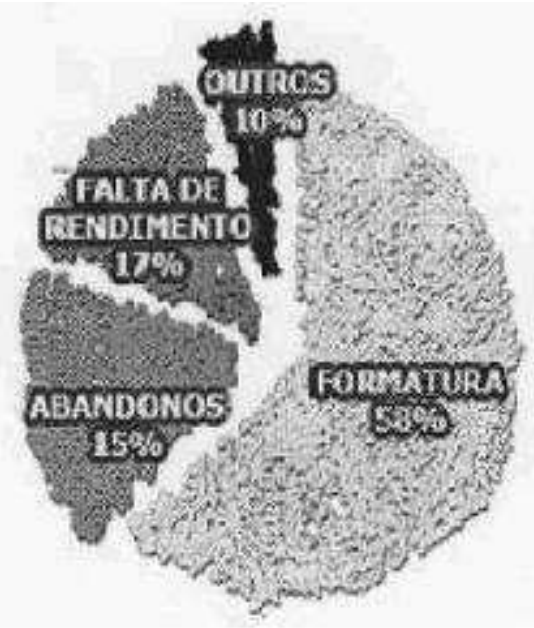

Gráfico 2

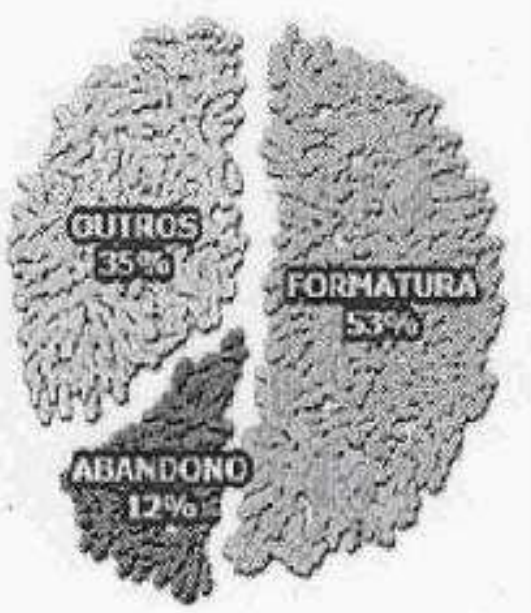

Gráfico 1 - Formas de saídas dos alunos no período de 2001 a 2006.

Fonte: DAIA/2008

Gráfico 2 - Formas de saídas dos alunos no período de 2007.

Fonte: DAIA/2008

A partir de pesquisas nas bases sistematizadas da Universidade e dados da DAIA que foram fornecidos pelos departamentos, foram obtidos os resultados constantes das Tabelas 5 e 6 que ilustram as taxas de concluintes no período de 2001 a 2006.

Tabela 5 - Cursos com alunos concluintes acima de $80 \%$

\begin{tabular}{l|c}
\hline Cursos & Porcentagem \\
\hline Pedagogia & $90,32 \%$ \\
Psicologia & $85,95 \%$ \\
Medicina & $84,77 \%$ \\
Arquitetura & $80,88 \%$ \\
Relações Internacionais & $80,81 \%$ \\
\hline
\end{tabular}

Fonte: DAIA/2008

Tabela 6 - Curso com alunos concluintes abaixo de $45 \%$

\begin{tabular}{l|c}
\hline Cursos & Porcentagem \\
\hline Química & $41,27 \%$ \\
Computação & $39,37 \%$ \\
Filosofia & $\mathbf{3 9 , 1 0 \%}$ \\
Física & $36,61 \%$ \\
Matemática & $34,26 \%$ \\
\hline
\end{tabular}

Fonte: DAIA/2008 
Atualmente, encontra-se em curso um estudo relativo a evasão na Universidade, conduzida por um professor do Instituto de Química, que considera faltar entender com precisão por que o aluno abandona o curso e destaca que para descobrir a taxa real de evasão é necessário que se avaliem os tipos de mobilidade interna que vai da transferência até o desligamento voluntário. No entanto, mudar de curso ou de habilitação não caracteriza que o aluno abandou e sim que deixou de ocupar uma vaga para preencher outra.

Dentro da proposta do Plano de Reestruturação e Expansão da Universidade de Brasília para o Programa (REUNI 2008, p.18), encontram-se as diretrizes para a aplicabilidade das características da mobilidade (citada pela Diretora da DAIA) no capítulo VI - chamada de Para criar mobilidade:

- Implantação de Sistema de Ingresso por Área de Conhecimento reunindo diversos cursos com afinidade epistemológica e curricular, nos termos definidos pelo CEPE;

- Minimização da oferta de disciplinas restritas;

- Uniformização de ementas e de nomes de disciplinas da Universidade de mesmo conteúdo, assim como a flexibilização da normatização para mudança de curso;

- Aperfeiçoamento de convênios com outras instituições públicas de ensino superior, visando promover uma real mobilidade interinstitucional;

- Viabilização de acordos de cooperação entre universidades para mobilidade acadêmica por meio de estratégias relacionadas a assistência estudantil aos estudantes (moradia estudantil, bolsas etc);

- $\quad$ Flexibilização do aproveitamento de estudos realizados por meio de intercâmbio nacionais e internacionais.

Ainda como diretrizes a serem tratadas pelo Plano de Reestruturação e Expansão da Universidade (REUNI,2008, p.62), encontra-se o item chamado de Mobilidade Intra e Interinstitucional, que garante: a ampla mobilidade estudantil mediante o aproveitamento de créditos e a circulação de estudantes entre cursos e programas de educação superior.

A Diretora da DAIA cita que, dentre as formas de ingresso existentes na Universidade, esta mantém acordos de cooperação e intercâmbio com cerca de 120 instituições de ensino superior e organismo \& associações internacionais, chamados pelo SIGRA de convênios (CON), distribuídos por todos os continentes, bem como participa de diversos programas oficiais de mobilidade e cooperação. Alguns exemplos podem ser citados: programas PEC-G e PEC-PG, matrícula cortesia (para membros de representações 
diplomáticas e seus dependentes), MARCA-MERCOSUL (Mobilidade Acadêmica Regional para as Carreiras Acreditadas), PROMISAES e Programa Luso-Brasileiro de Bolsas Santander - Universidades, entre outros.

Apesar do desconhecimento das instituições relativo ao fenômeno da evasão discente, é possível mediante estudos encontrar disponíveis em bases de dados existentes nestas instituições, fundamentos capazes de nortear essa questão. Para tanto, tornam-se necessárias informações que possam ser capturadas e formalmente representadas por dados reais, utilizando-se de um modelo de raciocínio, e metodologias já existentes e avaliadas dentro de cada uma destas instituições.

\subsubsection{Caracterização dos participantes da pesquisa}

O número de alunos selecionados para participar neste estudo (evadidos) foi igual a 24 alunos, sendo 11 mulheres e 13 homens. Dentre os 46 inicialmente identificados como evadidos para este estudo (22 foram reintegrados e concluíram o curso em uma das habilitações no segundo semestre de 2008), restando apenas 24 alunos realmente afastados da Instituição, considerados evadidos a partir do conceito adotado neste estudo que evasão é o abandono do curso, desses cinco responderam ao questionário enviado por intermédio da agência dos correios e por e-mail.

Participaram do estudo três homens e duas mulheres, com idade entre 24 e 44 anos, com três opções por bacharelado; uma com dupla habilitação; e outra com licenciatura. Um aluno cursou o primeiro período, outro até o sexto, e três cursaram até o segundo período. A forma de ingresso da maioria foi pelo vestibular, sendo que apenas um ingressou por meio do programa de avaliação seriada. E todos trabalhavam desde a ocasião em que faziam o curso na Universidade.

Dos professores do Departamento de Filosofia, 15 são do sexo masculino e duas do sexo feminino, todos com doutorado, sendo que quatro deles são estrangeiros, com uma faixa etária que varia de trinta e cinco aos sessenta anos.

\subsubsection{Respostas dos alunos evadidos}

Pela análise das respostas do questionário destinado aos alunos, constatou-se que o curso foi considerado regular, e os resultados das perguntas abertas mostraram que as 
desistências do curso se deram pelo fato de que a repetência nas disciplinas básicas foi muito grande.

A seguir, encontram-se os resultados organizados de acordo com as respostas dos questionários conforme a ordem de apresentação das questões.

\section{Motivos da escolha do curso de Filosofia}

$\mathrm{Na}$ percepção dos alunos que se evadiram do curso, dos cincos alunos que responderam o questionário, na Tabela 7 encontram-se as razões atribuídas por esses sujeitos.

Tabela 7 - Motivos que levaram o aluno a escolha do curso de Filosofia

\begin{tabular}{lc}
\hline \multicolumn{1}{c}{ Motivos } & Freqüência \\
\hline Curiosidade ou interesse pela Ciência & 03 \\
Aspiração pela carreira acadêmica ou profissional de Filosofia & 02 \\
Dificuldade para ingressar em outro curso devido a concorrência elevada & 02 \\
Facilidade/gosto pela Filosofia no ensino médio & 01 \\
Incentivo de professores do ensino médio & 01 \\
\hline
\end{tabular}

Na Tabela 7, observa-se o predomínio da escolha pela curiosidade ou interesse pela ciência, enquanto que a aspiração pela carreira acadêmica e a dificuldade encontrada para ingresso em outro curso foram menos indicados como razões da escolha do curso.

Constata-se, segundo Paul e Silva (1998), que o desempenho acadêmico e a intenção de trabalhar constituem variáveis de especial relevância na escolha. Com efeito, os candidatos que tiverem melhor desempenho acadêmico têm uma tendência em fazer sua opção pela carreira de maior prestígio.

Em relação à questão relativa à participação em atividades oferecidas pela instituição (PIBIC, Monitoria, PET, Projetos de Extensão) no período do curso, constatou-se que nenhuns dos cincos alunos participaram.

Na Tabela 8, é descrita a visão dos alunos quanto ao seu desempenho nas disciplinas do grupamento básico oferecidas pelo curso. 
Tabela 8 - Desempenho dos alunos nas disciplinas básicas do curso de Filosofia

\begin{tabular}{l|c}
\hline Auto Avaliação & Freqüência \\
\hline Péssimo & 02 \\
Ruim & 02 \\
Regular & 01 \\
\hline
\end{tabular}

Percebe-se que os alunos se auto-avaliam com baixo desempenho nas disciplinas do grupamento básico oferecidas pelo FIL nos três primeiros semestres.

Isso pode ser devido ao que Almeida e Veloso (2002) destacam em relação ao ambiente externo, ou seja, há por parte do jovem estudante uma grande expectativa em relação ao ambiente universitário, frustrada pelas dificuldades de adaptação e pelas profundas diferenças em relação ao ambiente escolar do ensino médio. Neste aspecto, constatou-se o baixo desempenho do aluno nos três primeiros semestres, onde se encontram as disciplinas básicas do curso.

Na Tabela 9, é descrita a avaliação dos alunos quanto ao seu desempenho nas disciplinas do grupo básico cursadas em outros cursos/institutos.

Tabela 9 - Desempenho dos alunos em disciplinas de outros Institutos

\begin{tabular}{l|c}
\hline Desempenho & Freqüência \\
\hline Bom & 03 \\
Ruim & 01 \\
Péssimo & 01 \\
\hline
\end{tabular}

Nesta questão, observa-se que o aluno obteve maior desempenho quando sai da cadeia de disciplinas do curso de Filosofia. Para Almeida e Veloso (2002), o bom desempenho do aluno está diretamente ligado a um processo de ensino-apredizagem, e a transferência de conhecimentos constitui uma tarefa que não pode ser completada se não houver um conjunto de motivação, ou seja, por parte do docente e da Instituição. Afirmam ainda os autores que devido à grande expectativa pelo ambiente universitário, este tem seus sonhos frustrados quando se depara com as dificuldades encontradas no novo ambiente, diferente do que ele estava habituado no ensino médio, onde recebia por parte da escola e professores todas as atenções necessárias para o seu bom desempenho escolar. 
A opinião dos alunos em relação ao desempenho no grupamento das disciplinas profissionais consta na Tabela 10.

Tabela 10 - Desempenho dos alunos em disciplinas do grupo profissional

\begin{tabular}{l|c}
\hline Desempenho & Freqüência \\
\hline Ruim & 02 \\
Péssimo & 01 \\
Regular & 01 \\
Bom & 01 \\
\hline
\end{tabular}

$\mathrm{O}$ curso oferece duas opções: bacharelado e licenciatura. $\mathrm{O}$ aluno quando perguntado a respeito de o seu desempenho nas disciplinas profissionais, demonstra que quando se tratam de disciplinas referentes ao curso, o seu desempenho é baixo.

Perguntados quanto a reprovações em algumas disciplinas do curso, todos os alunos mencionaram que foram reprovados em várias disciplinas, conforme descrição a seguir: Lógica, IPF, História da Filosofia Antiga, Estudos Metafísicos e Hermenêutica.

Confirma-se a observação feita na questão anterior, que o aluno encontrou dificuldades para um bom desempenho nas disciplinas do módulo profissional.

Quando perguntados se houve alguma mudança no curso após o ingresso na Universidade, foram apresentadas as respostas constantes da Tabela 11.

Tabela 11 - Mudanças no curso após ingresso do aluno

\begin{tabular}{l|c}
\hline Mudanças & Freqüência \\
\hline Continua a mesma & 03 \\
Melhorou & 01 \\
Não respondeu & 01 \\
\hline
\end{tabular}

Nesta questão os alunos afirmaram que não houve mudança alguma que considerem importantes.

Na Tabela 12, encontram-se as respostas referentes ao grau de satisfação com o curso. 
Tabela 12 - Grau de satisfação do aluno com o curso de Filosofia

\begin{tabular}{l|c}
\hline Grau & Frequência \\
\hline Regular & 03 \\
Bom & 02 \\
Ruim & 01 \\
\hline
\end{tabular}

Neste aspecto, apenas um aluno avaliou o curso como ruim, mas a maior parte considerou que é um curso com um nível regular.

Quando perguntados quanto a causas de insatisfação se de ordem pessoal, ou da instituição ou ainda em ambos, a maioria (4) indicou que ambos, e apenas um sujeito considerou que a causa era de ordem pessoal.

Para melhor compreensão das respostas descritas nesta sessão, seguem trechos de relatos dos alunos:

"Como trabalho, o fato das aulas serem no período diurno dificultaram a minha permanência".

-"Estratégia didático-pedagógica"-

"E a disciplina de História da Filosofia Antiga é oferecida apenas em um semestre, e as avaliações são feitas com o conteúdo que não foi dado em sala de aula, a prova foi sobre toda a filosofia antiga, mas a limitação de tempo de aulas, cabia ao alunos estudarem por conta própria".

-"Falta de flexibilidade do curso"-

"Na falta da flexibilidade tanto da direção quanto da grade de cursos para com os alunos que trabalham diuturnamente".

"Considero-me um ex-aluno que possui o seguinte perfil: sou servidor público, com formação superior e com horário não flexível e jornada de trabalho de 40 horas semanais, ou seja 8 horas por dia com 2 horas de almoço. Fico insatisfeito de não ter conseguido liberação e da Universidade não fornecer para esse curso horário voltado para pessoas com o meu perfil”.

Quando perguntados a respeito dos fatores de ordem pessoal relacionado à evasão os sujeitos apresentaram as respostas apresentadas na Tabela 13: 
Tabela 13 - Fatores ligados às causas de evasão de ordem pessoal

\begin{tabular}{l|c}
\hline Causas & Frequência \\
\hline Dificuldade de adaptação & 03 \\
Falta de tempo & 03 \\
Problema de ordem pessoal & 03 \\
Deficiência de formação & 02 \\
Outros & 01 \\
Falta de perspectivas & 01 \\
\hline
\end{tabular}

A maioria afirmou que a falta de opção de horário, a dificuldade de adaptação e os problemas de ordem pessoal foram fatores que os levaram ao abandono do curso.

Para Paredes (1994), o fato de o estudante ter que trabalhar é uma das impossibilidades de se manter nos estudos e uma das causas de sua desistência dos cursos.

Em relação às causas geradas pela Instituição, os sujeitos responderam o seguinte:

Tabela 14 - Causas de evasão geradas pela Instituição

\begin{tabular}{|c|c|}
\hline Causas & Frequência \\
\hline $\begin{array}{l}\text { Alguns professores do FIL } \tilde{n} \\
\text { atenderam à expectativa }\end{array}$ & 03 \\
\hline $\begin{array}{l}\text { Algumas disciplinas tinham alto grau } \\
\text { de dificuldades }\end{array}$ & 02 \\
\hline $\begin{array}{l}\text { Professores do FIL em geral } \tilde{n} \\
\text { atenderam à expectativa }\end{array}$ & 01 \\
\hline $\begin{array}{l}\text { Programa das disciplinas do FIL } \tilde{n} \\
\text { foram adequados }\end{array}$ & 01 \\
\hline $\begin{array}{l}\text { Alguns livros adotados no FIL } \tilde{n} \\
\text { foram adequados }\end{array}$ & 01 \\
\hline $\begin{array}{l}\text { Currículo da habilitação escolhida } \tilde{n} \\
\text { foi adequado }\end{array}$ & 01 \\
\hline $\begin{array}{l}\text { Desconhecimento de normas da } \\
\text { Universidade }\end{array}$ & 01 \\
\hline Outros & 01 \\
\hline
\end{tabular}


Para os alunos, foram considerados vários aspectos que o levaram ao abandono do curso, sendo o mais marcante a insatisfação com alguns professores e disciplinas.

Para Sbardelini (2001), o ensino universitário brasileiro ainda não consegue oferecer cursos que se identifiquem com a necessidade do país, pois hoje o país se encontra em total crescimento e desenvolvimento que sofre com a necessidade de profissionais que condizem com essas características. Segundo Freitas (2007), dentre tantos debates e estudos realtivos a formação da docência para o ensino superior, não basta apenas o domínio do conteúdo específico, mas ser professor está além de características históricas e exclusiva transmissão de conhecimento, torna-se necessária a formação científica, pedagógica, prática, técnica e política, desenvolvendo assim, as competências profissionais de um educador.

As respostas à questão 12: suas insatisfações o levaria a abandonar o curso? Confirmam os dados obtidos em algumas questões anteriores, pois todos os cinco estudantes optaram por SIM, exemplificando:

"A dificuldade em conciliar o trabalho com os estudos impede o aproveitamento adequado das matérias. Acabei por faltar em algumas aulas para não prejudicar o trabalho. Se houvesse um curso no período noturno, seria mais adequado para quem faz a segunda graduação como eu".

"Não tinha motivação".

"Não era o curso que eu gostaria a principio ....."

Percebe-se que o aluno, além de suas dificuldades de adaptação, enfrentou também dificuldade de conciliação dos estudos com o trabalho e a própria desmotivação com o curso de graduação.

A questão seguinte: Caso tenha escolhido a opção sim, quais foram as decisões tomadas na ocasião. Todos os cinco alunos que disseram SIM, quatro desses alunos atribuíram a sua resposta ao fato de terem abandonado o curso superior, pelo menos por algum tempo, e um aluno atribuiu a sua resposta a OUTROS, especificando que abandonou para dar prioridade a outro curso que já estava fazendo em outra instituição. Seguem respostas desses sujeitos:

“Abandonou o curso para dar prioridade a outro em outra instituição devido ao fato de neste estar mais adiantado no que diz respeito às disciplinas a serem cursadas na época". 
Mediante o exposto, considera-se que os aspectos apontados por Oliveira e Souza (2004) que percebem um perfil novo de estudante evadido (aquele que já cursou um curso superior) seja por motivos de trabalho ou sócio-cultural, que pode ser o perfil que expressa a realidade vivenciada pelos alunos do curso de Filosofia da Universidade.

Para a questão de número 14, foi solicitado que o aluno desse sua sugestão em relação ao curso. Três alunos deixaram sua contribuição, conforme a seguir:

-"Curso noturno para alunos que trabalham".

"Sugiro ser ofertado o mesmo curso em horário que atenda pessoas com o meu perfil".

"Disposição de disciplinas obrigatórias da grade de bacharel/licenciatura no período noturno. Maior suporte por parte da direção do curso aos alunos iniciantes. Melhoria da qualidade de atendimento por parte da secretaria do curso de Filosofia aos alunos. Aumento do período para inclusão/retirada de disciplinas, pelo menos uma semana a mais".

-“Disciplinas em visão mais contemporânea: Na disciplina de História da Filosofia Antiga há uma dificuldade no foco ou se aprofundam em poucos assuntos específicos ou se estudam muitos assuntos de forma superficial. Da forma como está, há dificuldade para o aluno acompanhar o curso. A aula é aprofundada sobre poucos assuntos específicos ao mesmo tempo em que a avaliação exige um auto-didatismo do aluno para que o restante da matéria seja feita de forma superficial e individual. E a seqüência do fluxo, que obriga o aluno a cursar as disciplinas de História da Filosofia em ordem cronológica, engessa a visão da Filosofia como evolução no tempo, o que prejudica todo o curso. Mesmo porque os autores antigos são analisados segundo estudos contemporâneos, que os atualizam no tempo".

No final do questionário, foram incluídos itens com os seguintes dados demográficos: sexo, idade, habilitação do curso, até que semestre cursou em que semestre saiu da Universidade, forma de ingresso e se trabalha. As respostas a esses itens foram apresentadas no tópico 15, da seguinte forma: três fizeram a opção por bacharelado, um pela opção em licenciatura e o outro a opção por dupla habilitação. Os semestres cursados foram: um cursou até o sexto semestre, dois cursaram até o segundo semestre e dois cursaram somente o primeiro semestre. Quanto as suas saídas da Universidade aconteceram em: um saiu no segundo semestre de 2006, outro saiu no primeiro semestre de 2007 e o outro saiu no segundo semestre de 2007, dois alunos não identificaram o ano de suas saídas. Quanto à 
forma de ingresso na Universidade: quatro alunos ingressaram por meio do vestibular e um por meio do PAS. E, perguntados se trabalham, todos responderam SIM.

Este aluno traz consigo um aspecto que demonstra falta de experiência o que é percebida logo após o seu ingresso. A partir daí ele se depara com o fator adaptação, ou seja, ele é movido por expectativa infundada a respeito do curso, profissão e instituição. Desapontado com o curso superior este aluno depara-se com reprovações, o que o leva a se desmotivar também com a Instituição e com o corpo docente, ele então passa a considerar a possibilidade de desistência.

O outro perfil do aluno evadido é aquele que diante das dificuldades sócioeconômicas tenta conciliar a jornada de trabalho com o horário oferecido pelo curso.

Portanto, a escolha de um curso superior de formação de professores não significa necessariamente uma opção e, muitas vezes, o desencontro entre as expectativas do aluno e a realidade da universidade que o leva ao abandono do curso.

\subsubsection{Análise das respostas dos professores}

$\mathrm{Na}$ análise do questionário aplicado junto aos professores do Curso de Filosofia da Universidade, foi unânime a avaliação feita pelos docentes a respeito das principais causas da evasão dos alunos no curso: o desconhecimento do curso. A seguir encontra-se uma resposta de um professor que ilustra tal conclusão.

"Que os que ingressam pela primeira vez na universidade, vindos diretamente do ensino médio, a causa maior é o desconhecimento do curso. Muitos procuram a filosofia baseados na experiência da disciplina filosofia que tiveram na escola, que, muitas vezes, tem um sentido bem diferente do que se faz na universidade nos departamentos de filosofia. $\mathrm{O}$ curso de filosofia também é bem mais exigente do que muitos imaginam, e o choque pode levar à desistência. Há ainda os que procuram o curso por que imaginam ser uma porta de entrada mais fácil, com um vestibular menos concorrido, mas, sem outro estímulo, acabam desencorajados pelas dificuldades da disciplina. Para os muitos alunos que já têm um curso superior completo e voltam à universidade para complementar sua formação ou para aqueles que cursam outro curso em outra instituição de ensino superior, a desistência é, muitas vezes, resultado de terem já aproveitado do curso o que queriam. Como não necessitam de mais um 
diploma, abandonam o". curso quando já aproveitaram o que queriam. Também é para ele mais fácil abandonar (por já terem alternativas) quando encontram alguma dificuldade (acadêmica, profissional, familiar ou outra.)".

Quando perguntados quanto a que a Universidade pode fazer para reduzir a evasão, a maioria dos professores associou, a resposta ao baixo desempenho no ensino fundamental e médio.

Embora embasados na semelhança que a evasão no ensino superior tem com o fracasso no ensino fundamental, a sugestão foi geral quanto a procurar uma maior articulação com o ensino médio, de modo a dar a conhecer melhor o curso.

A Universidade é uma instituição voltada para formação de profissionais em várias áreas. No entanto, falta maior divulgação junto às comunidades a respeito do que esta sendo feito e desenvolvido para essa formação. Faz-se necessária a criação de projetos diferenciados como debates, palestras e conferências de temas vivenciados no dia a dia e apresentá-los as escolas, de forma que este aluno possa ainda no ensino médio conhecer as várias facetas de um curso de graduação.

Os professores deram as seguintes sugestões para se buscar minimizar a evasão: auxílio financeiro (bolsas), criação de curso noturno ou maior oferta de disciplinas no turno noturno e continuar com a política de reintegração, criação de um sistema mais eficiente de tutoria no percurso formativo do discente, maior aproximação com o ensino médio do filosófico acadêmico para a filosofia de conteúdo.

As Coordenações de Graduação tiveram a seguinte posição: que as questões financeiras; as necessidades de trabalhar e as reprovações nas disciplinas dissertações filosóficas 1 e 2 e lógica, são causas da evasão na filosofia. Quanto ao que consideram que a Instituição pode fazer para a redução da mesma, sugeriram que: se ofereçam bolsas; crie o curso noturno e se amplie a política de reintegração. Enquanto que a Coordenação de PósGraduação opinou da seguinte forma: a área é pouco atraente do ponto de vista financeiro e de perspectivas de emprego; o curso é bastante exigente academicamente e os alunos selecionados nem sempre têm condições de acompanhar as disciplinas; as disciplinas como lógica e dissertação filosófica (as que mais reprovam) têm problemas específicos: lógica tem carga horária pequena para o tamanho de seu conteúdo e dissertação filosófica é feita apenas em um semestre, quando deveria ter um período de projeto e de redação final, desenvolvido cada um num semestre; as disciplinas obrigatórias não são oferecidas todo semestre; não há 
um acompanhamento muito eficiente da trajetória dos graduandos (falta um sistema de tutoria mais eficiente); e, por último, os alunos já graduados têm pouco estímulo para fazer uma segunda graduação. A oferta de cursos de especialização pode ser uma alternativa mais interessante para esses casos. As considerações para redução da evasão foram apontadas pelos itens que mostram que a área é pouco atraente do ponto de vista financeiro e que o curso é bastante exigente academicamente, e não há o que a Instituição possa fazer, enquanto que os demais itens o departamento já está tomando iniciativas no sentido de solucionar os problemas.

Entretanto a Chefia do Departamento priorizou como principais causas à falta de conhecimento prévio e informação adequada quanto à escolha feita; dificuldades inerentes à própria matéria; possível decepção com a orientação filosófica e política da maioria dos professores; conflitos existenciais decorrentes do próprio estudo de filosofia; problemas econômicos; escolha da filosofia como segunda opção de curso, geralmente acompanhada de uma primeira opção num estabelecimento privado. E considerou para redução de evasão na Universidade, a oferta de uma ampla assistência estudantil. 


\section{CONCLUSÃO}

Neste trabalho foi possível constatar que o estudo relativo a evasão não deve se encerrar aqui, pois é clara a necessidade de sua continuidade, não só com a participação do corpo docente, mas principalmente com a do aluno evadido, que pode expressar todas as dificuldades encontradas em todo o trajeto do curso.

Percebeu-se um encontro de vários fatores que podem influenciar ou determinar a questão da evasão em uma IES. Dentre esses se encontram fatores internos e externos que podem causar e/ou determinar a decisão do aluno na Instituição.

A Universidade na qual foi feito o estudo no curso de Filosofia tem legislações internas e sistemas que definem o que é evasão "é toda forma de saída do aluno", diferenciando a questão da forma como ela é conceituada pela Comissão constituída pelo MEC que diz que evasão é diferente de exclusão, ou seja, a primeira corresponde a uma postura ativa do aluno que decide se desligar do ensino, enquanto que a outra admite que a responsabilidade é da escola por não ter mecanismo de aproveitamento e direcionamento do jovem que se apresenta para uma formação profissionalizante.

A partir daí tomou-se o sistema de informatização da Universidade chamado SIGRA e as informações prestadas pelos alunos evadidos, que fundamentou o objetivo central do estudo que é mostrar as razões que levam um aluno de ensino superior a abandonar o curso.

Pela análise dos dados do SIGRA, constatou-se que o número de alunos evadidos na licenciatura é menor que o do bacharelado. Pela informação dada pelos alunos foi possível verificar que o abandono é maior entre os alunos que ingressaram por meio do vestibular. Entre os estudantes evadidos três fatores estão associados ao abandono do curso: a situação de trabalho do estudante desde o seu ingresso, a reprovação em disciplinas, a incerteza quanto à carreira escolhida. Constatou-se ainda que de fato existia um baixo rendimento do aluno em algumas disciplinas oferecidas como obrigatórias, que também contribuíram para a evasão.

Este estudo, apoiado pela literatura que considera evasão o abandono por parte do aluno no ensino superior, vem sugerir que haja melhorias no sistema informatizado da IES caracterizando de forma expressiva o abandono do aluno no ensino superior e não tratando a mobilidade estudantil como forma de evasão. 
Sugere-se que novos estudos comparativos em diferentes anos e semestres sejam realizados com o propósito de explorar mais as causas de evasão, assim como ações possíveis objetivando sua redução. 


\section{REFERÊNCIAS}

AGUIAR, M. T. C. A evasão nos cursos de graduação da Universidade Federal de Mato Grosso, Campus Universitário de Cuiabá 1985/1995/2, um processo de exclusão. 2001. 193p. Dissertação (Mestrado em Educação) - Universidade Federal de Mato Grosso, Cuiabá, 2001.

ALMEIDA, E. P.; VELOSO, T. C. M. A. Evasão nos cursos de graduação da Universidade Federal de Mato Grosso, Campus Universitário de Cuiabá - um processo de exclusão. 2002.

BRASIL. Ministério de Educação e Cultura. Secretaria de Ensino Superior. Comissão Especial de Estudos sobre a Evasão nas Universidades Públicas Brasileiras. ANDIFES/ABRUEM, SESu. Brasília: MEC, 1995. 134 p.

BRAGA, M. M.; PINTO-MIRANDA, C. O B. de; CARDEAL, Z. de L. Perfil sócioeconômico dos alunos, repetência e a evasão no curso de química da UFMG. 1997.

BUENO, J. L. O. A evasão de alunos. Paidéia. FFCLRP-USP, Ribeirão Preto, 5, ago.1993.

CAPTAN, A H. O novo modo de ser, do saber e do aprender - construindo uma taxionomia para mediação pedagógica em tecnologia de comunicação digital. Tese de Dourado (Programa de Pós-Graduação em Engenharia de Produção). Universidade Federal de Santa Catarina, 2001.

CARVALHO, I. M. et. al. Estudos do fenômeno da evasão da Universidade da Bahia. Convênio INEP/UFBA, n.45/84.

CUNHA, A. M. Evasão do curso de Química da UnB: A interpretação do aluno evadido. 1997. 136p. Dissertação (Mestrado em Psicologia) - Universidade de Brasília, Brasília, 1997.

CUNHA, A. M.; TUNES, E.; SILVA, R. R. Evasão do curso de química da Universidade de Brasília: a interpretação do aluno evadido. Química Nova, São Paulo, v.24, n.2, p.262280, abr.2001.

DAL MAS DIAS, E. A dúvida da continuidade dos estudos universitários: uma questão Adolescente. Taubaté/SP: Cabral, 1997.

FINGER, A. P. Administração da Educação: questões que exigem respostas. p.96-112, 1997. 
FREITAS, M. A. de O.; SEIFFERT, O. M. L. B. Formação docente e o ensino de PósGraduação em Saúde: uma experiência na UNIFESP. Rev. Bras. Enfer. Brasília-DF, vol.60, n.6, Nov./Dec.2007.

GAIOSO, N. P. de L. O fenômeno da evasão escolar na educação superior no Brasil. 2005. Dissertação (Mestrado em Educação) - Universidade Católica de Brasília. Brasília, 2005 .

GILENO, F. M. (Org.). Gestão estratégica de universidade: o caso da FA/UnB. 2004.

MONTEIRO, N. Universidade Nova UFMG, 10 de abril de 2006. Disponível em: <http://www.universidadenova.ufba.br/twik/bin/view/Universidadenoval. Acesso em: 09/04/2009.

MOURA, D. H.; SILVA, M. dos S. A evasão no curso de Licenciatura em Geografia oferecido pelo CEFET-RN. 2007.

NASSAR, S. M. Sistemas especialistas probabilísticos. Disponível em: <http://inf.ufsc.br/ Silvia /SEP>. Acesso em: 10/2004.

OLIVEIRA, R. P.; SOUSA, S. M. Z, 2004. Relatório de Pesquisa "Acompanhamento da Trajetória Escolar dos Alunos da USP, ingressantes de 1995 a 1998”. São Paulo.

PAREDES, A. S. A evasão no terceiro grau em Curitiba. São Paulo: NUPES, 1994.

PEREIRA, L. de J. M.; LIMA, M. C. A. Evasão no curso de Física da UFMA nos primeiros períodos do curso. 2005.

PIAZZA, M. E. O papel das coordenações de cursos de graduação segundo a percepção de coordenadores em exercício da função. 1997. 213p. Dissertação (Mestrado em Educação) - Universidade Federal de São Carlos, São Carlos/SP, 1997.

Plano de Reestruturação e Expansão da Universidade de Brasília - REUNI. 2008-2012.

RAMOS, M. N. Quadro de evasão no UFPE: metodologia, causas e ações. Recife: Universidade Federal de Pernambuco, 1995. 
RIBEIRO, M. A. O projeto profissional familiar como determinante da evasão universitária - um estudo preliminar. Universidade de São Paulo. SP. 2005.

RIBEIRO, E. S.; MOURA, C. P.; ANDRIOLA, W. B. Evasão discente na Universidade Federal do Ceará: dados relativos aos anos 1999-2000. In: Encontro de Iniciação Científica e Tecnológica do Centro Federal de Educação Tecnológica (CEFET/CE). Anais. Fortaleza, n.3., 2003.

RISTOFF, D. A tríplice crise da universidade In: TRINDADE, Hélgio (Org.). Universidade em ruínas na república dos professores. Petrópolis/RJ: Vozes, 1999.

Evasão: exclusão ou mobilidade. Santa Catarina: UFSC, 1995

SALIBA, N. A; MOIMAZ, S. A. S.; RAPHAEL, H. S.; TIANO, A. V. P.; RODRIGUES, R. P. C. B.. Organização curricular, evasão e repetência no curso de odontologia: um estudo longitudinal. São Paulo, 2006.

SCHWARTZMAN, S. O ensino superior no Brasil. Brasília: Instituto Nacional de Estudos e Pesquisas Educacionais, 1999.

SEMESP, Sindicato das Entidades Mantenedoras de Estabelecimentos de Ensino Superior no Estado de São Paulo. Evasão.

SILVA, M. G. R. da. Coach e papéis gerenciais. In: RUAS, R.; ANTONELLO, C.; BOFF, L. H (Orgs.). Aprendizagem organizacional e competências. Porto Alegre: Bookman, 2005.

SILVA FILHO, R. L. et al. A evasão no ensino superior brasileiro. Cadernos de Pesquisa. São Paulo, v.37, n.132, set./dez.2007.

SBARDELINI, E. T. B. Identidade profissional e opção universitária. Psicol. Es. Educ. Campinas/SP, v.5 n.1, jun.2001.

VELloso, J. R. Perfil social, desempenho e chances em vestibulares com cotas: uma comparação na UnB. Brasília: NESUB e Faculdade de Educação. Universidade de Brasília, 2007. 54p. (mimeo). 